\title{
Spontaneous Shrinkage of a Suprasellar Arachnoid Cyst Diagnosed with Prenatal Sonography and Fetal Magnetic Resonance Imaging: Case Report and Review of the Literature
}

\section{Prenatal Ultrasonografi ve Fetal Manyetik Rezonans Görüntüleme ile Tanı Konan Bir Suprasellar Araknoid Kistin Kendiliğinden Küçülmesi: Olgu Sunumu ve Literatürün Gözden Geçirilmesi}

Ethem GOKSU, Saim KAZAN

Akdeniz University, School of Medicine, Department of Neurosurgery, Antalya, Turkey

Presented in: 41st Annual Meeting of the International Society for Pediatric Neurosurgery, 29 September -3 October 2013, Mainz, Germany.

Corresponding Author: Ethem GOKSU / E-mail: ethemgoksu@mynet.com

\begin{abstract}
Arachnoid cysts (AC's) are congenital anomalies that occur within the cerebrospinal fluid (CSF) cisterns and major cerebral fissures. Suprasellar AC's comprise $5-12.5 \%$ of all the lesions. Despite being commonly reported, their etiology and pathogenesis still remain unclear. In this report, we presented an unusual case of spontaneous shrinkage of a suprasellar AC that had been incidentally diagnosed during a routine prenatal sonographic examination. To our knowledge, only three cases of spontaneous shrinkage of suprasellar AC have been reported in the literature. In detail of the manuscript, fetal and postnatal radiological images were presented and the possible mechanisms were discussed with a review of the literature.
\end{abstract}

KEYWORDS: Suprasellar arachnoid cyst, Spontaneous shrinkage, Fetal imaging

öz

Araknoid kistler (AK), beyin omurilik sıvıSı (BOS) sisternleri ve büyük serebral fissürlerde ortaya çıkan doğumsal anomaliler olarak tanımlanmaktadır. Suprasellar AK'ler tüm lezyonlar içerisinde $\% 5-12,5^{\prime}$ lik bir yere sahiptir. Sıkça karşılaşılan patolojiler olmakla birlikte, etyoloji ve patogenezleri halen net olarak anlaşılamamıştır. Bu yazıda, rutin prenatal ultrasonografik tarama sırasında tesadüfen saptanan ve kendiliğinden küçülme gösteren nadir bir suprasellar AK olgusu sunulmuştur. Bilgilerimize göre, suprasellar AK'lerin kendiliğinden küçülmesi ya da kaybolmasına dair şu ana dek literatürde üç olgu bildirilmiştir. Yazının detayında, fetal ve doğum sonrası radyolojik görüntüler sunulmuş, literatür verileri gözden geçirilerek kendiliğinden küçülmeye ya da kaybolmaya ilişkin altta yatan muhtemel nedenler tartışılmıştır.

ANAHTAR SÖZCÜKLER: Suprasellar araknoid kist, Kendiliğinden küçülme, Fetal görüntüleme

\section{INTRODUCTION}

Arachnoid cysts (AC's) are described as congenital lesions that occur within the cerebrospinal fluid (CSF) cisterns and major cerebral fissures. AC's constitute $1 \%$ of all intracranial lesions, and $5-12.5 \%$ of the lesions are located in the suprasellar region $(8,9,14)$. The natural history of the AC's still remains unclear due to the lack of long-term follow-up of untreated subjects. Most AC's can remain unchanged for many years with serial neuroimaging studies but some may progressively expand and cause compressive findings; and much more rarely, $A C$ 's may resolve spontaneously $(1,2,7,10)$. To our knowledge, there have been just three cases of spontaneous shrinkage reported in the existent literature. In this report, we presented a case of spontaneous shrinkage of suprasellar AC, incidentally diagnosed during a routine prenatal sonographic examination.

\section{CASE REPORT}

A round anechoic mass was detected in the midline suprasellar or third ventricle region of the fetal brain in a 23-year-old pregnant woman with a routine scan at the $25^{\text {th }}$ week of gestation (Figure 1A). The lesion was measured as approximately $18 \mathrm{~mm}$ in diameter and without Doppler flow. The size of the lateral ventricles was normal, and there were no other abnormalities. Arachnoid cyst, cystic neoplasms of the sellar or suprasellar region were considered as possible differential diagnoses. Porencephalic cysts were excluded 
because it was creating a mild mass effect. Intracranial hemorrhage was also excluded because of its form and anechoic appearance. We did not find any abnormality on infectious marker screening. Fetal magnetic resonance imaging (MRI) confirmed the cystic lesion at a suprasellar location (Figure 1B, C). Sagittal views demonstrated that there was displacement of the brainstem posteriorly but ventricular circulation was not obstructed. The corpus callosum development was normal. The sonography and fetal MRI findings indicated a possible diagnosis of $A C$ and the family was informed about the prenatal findings and neonatal prognosis.

A $2855 \mathrm{~g}$ girl was born with C/S at the $38^{\text {th }}$ week with Apgar scores of 7,9 , and 10 , at the $1^{\text {st }}, 5^{\text {th }}$, and $10^{\text {th }}$ minutes respectively. The baby was monitored at our neonatal intensive care unit. Her head circumference at birth was within the $50^{\text {th }}$ percentile. Neonatal screening tests were in normal range and there was nothing to suggest any endocrine, ophthalmological, or neurological deficit. Her vital findings were stable and she was discharged four days later.

MRI obtained on the $10^{\text {th }}$ day demonstrated a cystic lesion with a diameter of $27 \mathrm{~mm}$ within the prepontine and suprasellar cisterns with CSF intensity on all sequences (Figure 2A, B). Additional findings included an upward displacement of the optic chiasm, third ventricle floor, and ventral compression of the pons and midbrain without ventricular dilatation. Since the subject had a normal neuroophthalmological and endocrine status and no findings of elevated intracranial pressure, it was decided that the patient would be followed up without intervention. Curiously, the cyst was observed to progressively shrink to a final diameter of $8 \mathrm{~mm}$ in the followup MRI's taken at the $12^{\text {th }}$ and $24^{\text {th }}$ months. Furthermore, with the volume of the cyst having decreased, the third ventricle and aqueduct appeared clear and brainstem compression had disappeared (Figure 2 C, D).

\section{DISCUSSION}

Congenital AC's are benign CSF accumulations between the dura and the neural substance along the cerebrospinal axis. These lesions are composed of several layers of arachnoid cells strengthened with the collagen fibers and have been hypothesized to develop because of the splitting or duplication of the arachnoid membrane in the early developmental period $(8,9,13)$. As they are accepted to be a developmental origin, they can be identified in fetal imaging. Glioependymal cysts, craniopharyngiomas, benign cystic gliomas, Rathke cleft cysts, and colloid cysts of the third ventricle should be considered as possible differential diagnoses $(4,5)$. AC's classically are not contrast-enhanced lesions and they follow CSF intensity in all MRI sequences. Prenatal MRI is helpful to confirm the diagnosis and also demonstrate the additional findings of corpus callosum and cortical gyral abnormalities. Furthermore, diagnostic accuracy is a very important reason for genetic counseling and continuation of pregnancy. AC's at a suprasellar location can grow and cause obstructive

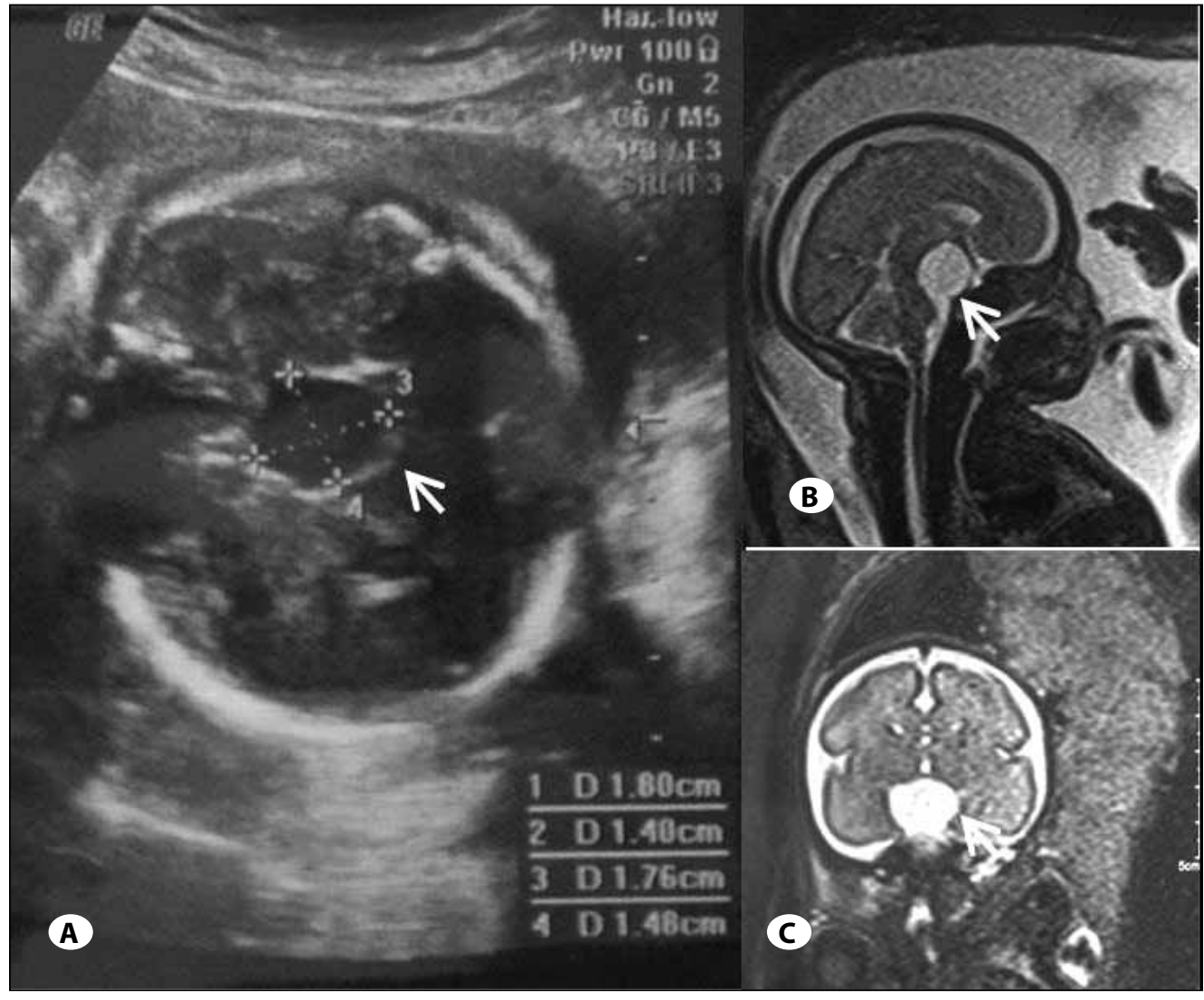

Figure 1: Prenatal sonographic examination at the $25^{\text {th }}$ gestational week (A), T2W sagittal (B) and coronal (C) fetal MRI demonstrate a midline cyst measuring $18 \mathrm{~mm}$ in diameter. 


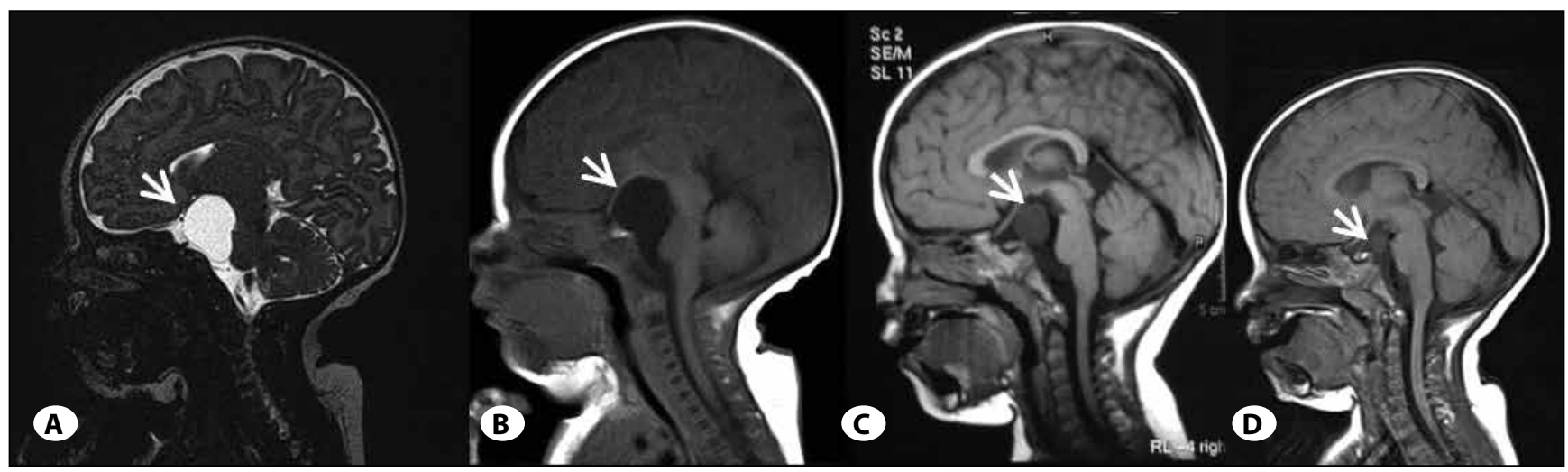

Figure 2: Sagittal T2W (A) and T1W (B) MR images at postpartum $10^{\text {th }}$ day show the suprasellar arachnoid cyst with a diameter of 27 $\mathrm{mm}$. Follow-up sagittal plane T1W MR images performed at the $12^{\text {th }}(\mathbf{C})$ and $24^{\text {th }}$ months (D) showed that the cyst had progressively shrunk to a final diameter of $8 \mathrm{~mm}$. Additionally the third ventricle and aqueduct appeared clear and brainstem compression had dissolved with the reduction of cyst volume.

hydrocephalus. Therefore, they should be carefully followed by serial sonographic examinations $(4,5)$. In our case, prenatal sonography, MRI and postnatal follow-up allowed us to make an early diagnosis, to identify the exact location of the cyst, to exclude other sellar lesions, and to evaluate the gradual resolution of the cyst.

AC's are predominantly observed in children (12). Their incidence has increased with the frequent use of routine scanning for various reasons. In a recent report, the frequency of $A C$ has been reported as $2.6 \%$ in over 10.000 children under 18 years of age who underwent brain imaging (1). There is also much debate regarding their natural history and management $(1,2,9,14)$. However, several parameters should be kept in mind in AC management. Firstly, the presence of other anomalies, such as agenesis of the corpus callosum should be determined. Secondly, the associated obstructive hydrocephalus should be evaluated, and finally, whether the size has changed with gestational progress and during postnatal follow-up should be assessed (5).

The management strategy of the AC's is basically determined by the patient's symptomatology and radiological progression. Patients with a presence of mass effect of the AC or increased intracranial pressure signs are candidates for surgery. The degree of brain re-expansion is variable following fenestration of the cyst and it is not related to cyst volume or surgical technique. However, AC's can be completely resolved both in children and adults (12). This entity was explained with the mechanism of much more rapid drainage of the cyst in patients with spontaneous resolution than that of cases who were surgically treated (12).

Enlargement of AC's has been reported previously $(1,2,6,7)$. There are also several hypotheses that have been suggested regarding the growth of the cyst: the ball-valve mechanism based on the differential flows between the AC and normal CSF, fluid production by the cells lining the walls of the cyst, and fluid movements secondary to pulsations of the veins. Furthermore, in the pathogenesis of suprasellar AC's, a slit-valve hypothesis, between the cyst and subarachnoid space via the pierced prepontine arachnoid membrane by the basilar artery, has been proposed. However, there is little information regarding the natural history in terms of symptomatology or size of $A C(1,2,7,9)$. Recently, the natural history of 111 pediatric patients with AC was evaluated with a mean follow-up of 3.5 years. In this series, the volume of the AC's were observed to be enlarged in $11 / 111$ patients and all of these patients were younger than 4 years of age (1). Lee et al. (7) demonstrated that AC's diagnosed before 6 months of age enlarged in size during follow-up significantly more frequently than in the older group. It has been reported that younger age was the only significant factor affecting the growth of AC's among other factors such as location, initial size, and duration of follow-up. Our case, in whom suprasellar AC's were diagnosed in the prenatal period, had continued her normal development until 30 months of age with no symptoms and signs of ophthalmological, endocrine or hydrocephalic complication and without any intervention.

The frequency of spontaneous shrinkage of $A C^{\prime}$ 's is probably higher than the reports in the literature $(10,12,15,16)$ as many $A C$ 's are asymptomatic and they are incidentally diagnosed as in the present case. The $A C$ in most of the subjects in which spontaneous resolution was reported originated in the middle fossa $(11,12)$. In the literature, there have been only three cases of spontaneous shrinkage of AC's located in the suprasellar region. Different mechanisms have been proposed to explain the pathogenesis of spontaneous resolution. The hypotheses have focused mainly on occurrences of communication between the cyst and normal CSF pathways, caused by events such as head injury or infection $(12,15,16)$. Rupture and collapse of the cyst as a result of increasing intracystic pressure with the effect of some provocating factors, such as extreme holding of the breath, crying or the Valsalva maneuver has been proposed as a possible mechanism by Yamauchi et al. (15). The studies have indicated a common relationship between subdural hematomas and arachnoid cysts but spontaneous disappearance of those cysts has not 
Table I: Summary of Reported Cases with Suprasellar Arachnoid Cyst that Resolved Spontaneously

\begin{tabular}{|l|c|c|c|c|}
\hline Author / Year & Age (years) / Sex & Triggering Event & $\begin{array}{c}\text { Necessity of VP } \\
\text { shunt }\end{array}$ & $\begin{array}{c}\text { Time of } \\
\text { Resolution } \\
\text { Regree of }\end{array}$ \\
\hline Dodd et al., 2002 (3) & Prenatal / F & None & No & $\begin{array}{c}\text { Significant } \\
\text { reduction }\end{array}$ \\
\hline Moon et al., 2007 (8) & $5 / \mathrm{M}$ & $\begin{array}{c}\text { None } \\
\text { (VP shunt ?) }\end{array}$ & Yes \\
\hline Thomas et al., 2009 (13) & Neonatal/M & $\begin{array}{c}\text { None } \\
\text { (VP shunt ?) }\end{array}$ & Yes & 10 years \\
\hline Present case & Prenatal / F & None & No & Active \\
\hline decompression
\end{tabular}

F: Female, M: Male, VP: Ventriculoperitoneal.

been documented (10). Dodd et al. (3) proposed that fluid was drained at a widening of the slit valve portion around the basilar artery and this drainage caused cyst decompression particularly in the prepontine component. Thomas et al. (13) reported a male infant with a large prepontine-suprasellar AC that decompressed spontaneously into the ventricular system, as demonstrated with a CSF flow jet on MRI. However, ventriculoperitoneal shunt (VPS) surgery was required for this subject. The VPS might actually have been the reason for spontaneous resolution in the case of Moon et al. (8). We could only speculate that the osmotic pressure gradient between the cyst and the subarachnoid space was a possible mechanism to explain the spontaneous decrease in the size of the $A C$ in our patient. The pathogenesis underlying this process needs to be further investigated. Table I summarizes the reported cases with spontaneously resolved suprasellar arachnoid cyst.

In conclusion, the natural history and the management of AC's are complicated. Spontaneous resolution can be expected to be much more frequent than assumed within the natural course of the lesion. The possibility of spontaneous shrinkage or disappearance of AC's should be borne in mind particularly in asymptomatic cases.

\section{REFERENCES}

1. Al-Holou WN, Yew AY, Boomsaad ZE, Garton HJ, Muraszko KM, Maher CO: Prevalence and natural history of arachnoid cysts in children. J Neurosurg Pediatr 5: 578-585, 2010

2. Cress M, Kestle JRW, Holubkov R, Riva-Cambrin J: Risk factors for pediatric arachnoid cyst rupture/hemorrhage: A casecontrol study. Neurosurgery 72: 716-722, 2013

3. Dodd RL, Barnes PD, Huhn SL: Spontaneous resolution of a prepontine arachnoid cyst. Case report and review of the literature. Pediatr Neurosurg 37(3): 152-157, 2002

4. Fujimura J, Shima $Y$, Arai $H$, Ogawa $R$, Fukunaga $Y$ : Management of a suprasellar arachnoid cyst identified using prenatal sonography. J Clin Ultrasound 34(2): 92-94, 2006

5. Gedikbasi A, Palabiyik F, Oztarhan A Yildirim G, Eren C, Ozyurt SS, Ceylan Y: Prenatal diagnosis of a suprasellar arachnoid cyst with 2- and 3- dimensional tomography and fetal magnetic resonance imaging. Difficulties in management and review of the literature. J Ultrasound Med 29: 1487-1493, 2010

6. Halani SH, Safain MG, Heilman CB: Arachnoid cyst slit valves: The mechanism for arachnoid cyst enlargement. Report of five cases. J Neurosurg Pediatrics 12: 62-66, 2013

7. Lee JY, Kim JW, Phi JH, Kim SK, Cho BK, Wang KC: Enlarging arachnoid cyst: A false alarm for infants. Childs Nerv Syst 28: 1203-1211, 2012

8. Moon KS, Lee JK, Kim JH, Kim H: Spontaneous disappearance of a suprasellar arachnoid cyst: Case report and review of the literature. Childs Nerv Syst 23: 99-104, 2007

9. Pascual-Castroviejo I, Roche MC, Martinez Bermejo A, Arcas J, Garcia Blazquez M: Primary intracranial arachnoid cysts: A study of 67 childhood cases. Childs Nerv Syst 7: 257-263, 1991

10. Rakier A, Feinsod M: Gradual resolution of an arachnoid cyst after spontaneous rupture into the subdural space. J Neurosurg 83: 1085-1086, 1995

11. Russo N, Domenicucci M, Rojas Beccaglia M, Santoro A: Spontaneous reduction of intracranial arachnoid cysts: $A$ complete review. Br J Neurosurg 22(5): 626-629, 2008

12. Seizeur R, Forlodou P, Coustans M, Dam-Hieu P: Spontaneous resolution of arachnoid cysts: Review and features of an unusual case. Acta Neurochir (Wien) 149:75-78, 2007

13. Thomas BP, Pearson MM, and Wushensky CA: Active spontaneous decompression of a suprasellar-prepontine arachnoid cyst detected with routine magnetic resonance imaging. Case report. J Neurosurg Pediatrics 3: 70-72, 2009

14. Wang JC, Heier L, Souweidane MM: Advances in the endoscopic management of suprasellar arachnoid cysts in children. J Neurosurg 100: 418-426, 2004

15. Yamauchi T, Saeki N, Yamaura A: Spontan disappearance of temporo-frontal arachnoid cyst in a child. Acta Neuruchir (Wien) 141: 537-540, 1999

16. Yoshioka H, Kurisu K, Arita K, Eguchi K, Tominaga A, Mizoguchi $\mathrm{N}$, Tajima T: Spontan disappearance of a middle cranial fossa arachnoid cyst after suppurative meningitis. Surg Neurol 50: 487-491, 1998 